\author{
MARGRETA GRIGOROVA \\ (iD https://orcid.org/0000-0003-4416-371X \\ Uniwersytet im. św. św. Cyryla i Metodego \\ Veliko Tyrnovo
}

\title{
Głos Olgi Tokarczuk w Bułgarii, czyli jak odnaleźć zgubioną duszę
}

Olga Tokarczuk's voice in Bulgaria, or how to find our lost soul

\begin{abstract}
The text presents aspects of Olga Tokarczuk's Bulgarian reception: translations, interviews, Bulgarian contacts, and an overview of her visit to Bulgaria in 2014. Special attention was paid to her creative friendship with Georgi Gospodinov. The Bulgarian initiatives related to Tokarczuk's Nobel Year are presented, including the publication of the wonderful book The Lost Soul, the second edition of the novel Flights and a series of publications in the press.
\end{abstract}

Key words: Olga Tokarczuk, Bulgarian reception, Nobel, The Lost Soul, Nobel Lecture:

The Tender Narrator

\section{Rok noblowski Olgi Tokarczuk}

Olgę Tokarczuk łączy z Bułgarią: siedem przetłumaczonych książek ${ }^{1}$ oraz sporo przełożonych esejów i opowiadań opublikowanych w prasie literackiej, dwie wizyty i szereg wywiadów², przyjaźń i bliskość twórcza z bułgarskim pisarzem Georgim Gospodinovem.

\footnotetext{
1 Аом дневен, до нощен [Dom dzienny, dom nосny], 2005, przeł. H. Simeonova-Mitova; Музика на много барабани [Gra na wielu bebenkach], 2006, przeł. S. Borisova; Последни истории [Ostatnie bistorie], 2008, przeł. M. Kostova; Правек и други времена [Prawiek i inne czasy], 2008, przeł. G. Krystev; Бегуни [Bieguni], 2009, przeł. S. Borisova; Kapaй nуга си през костите на мъртвите [Prowadź swój plug præez kości umarlych], 2013, przeł. S. Borisova; Изzyбeнama dyua [Zgubiona dusza], 2019, przeł. S. Borisova.

2 Po raz pierwszy Tokarczuk zawitała do Bułgarii w latach 90. Była to wizyta turystyczna, druga - oficjalna - nastąpiła w 2014 roku w ramach Polskiej Jesieni Literackiej. Większość wywiadów z pisarką przeprowadzono podczas drugiej wizyty.
} 
Obecnie wszystko, co związane jest z Olga Tokarczuk, wpisuje się w kontekst Literackiej Nagrody Nobla. Głos laureata staje się donośniejszy i lepiej rozpoznawalny. To, co mówi noblista, słyszy cały świat. Świadoma tego faktu pisarka podczas gali w Sztokholmie wygłosiła esej Czuły narrator, w którym przedstawiła swoje poglądy, po czym odpowiedziała na wiele pytań w czasie spotkań autorskich i wywiadów, które w Bułgarii śledziliśmy z zapartym tchem.

Latem 2019 roku, kilka miesięcy przed ogłoszeniem laureatów Nagrody Nobla, wyszło drukiem drugie wydanie Biegunów w przekładzie Silvii Borisovej (pierwsze, już wyczerpane, ukazało się w 2009 roku, dwa lata po publikacji w Polsce książki wyróżnionej Nagrodą Literacką „Nike”). Wnikliwa recenzję Biegunów, autorstwa Katii Atanasovej, opublikowano w czasopiśmie „Kultura” (Атанасова 2019). Uzupełnieniem tekstu był wywiad z tłumaczką (Борисова 2019b). Dzięki przekładowi Borisovej pod koniec września bułgarscy czytelnicy mogli zapoznać się tė̇ z wykładem Tokarczuk zatytułowanym Powiem wam, kto uratuje świat (Токарчук 2019b, 32-33), który pisarka wygłosiła podczas czwartej edycji Gdańskich Spotkań Literackich „Odnalezione w tłumaczeniu" (11-13.04.2019).

Nobel dla Tokarczuk to spełnienie naszych oczekiwań. Obchodziliśmy w Bułgarii ten fakt jak uroczyste, radosne święto. Pierwszy dłuższy artykuł w prasie (oprócz krótkich wiadomości w aktualnościach) opublikowano w czasopiśmie „Literaturen Vestnik”, gdzie pojawił się wywiad z Silvią Borisova (Борисова 2019a, 12-13) - tłumaczką uznaną za głos Olgi Tokarczuk w Bułgarii. Borisova, która przełożyła na bułgarski cztery książki Tokarczuk oraz wiele jej esejów i opowiadań, mówi: „niezależnie od tego, czy pisze książki na tematy historyczne albo aktualne, Olga już dawno znalazła swoje miejsce wśród czytelników i kręgów literackich absolutna współczesnością idei i myślenia” (Борисова 2019a, 12). W tym samym numerze „Literaturen Vestnik” Borisova opublikowała przekład opowiadania noblistki Rubié், związanego z bolesnym tematem uchodźstwa i migracji (Токарчук 2019a, 13-14).

Tydzień później wyszedł, planowany od kilku miesięcy (wtedy Nagroda Nobla dla Olgi Tokarczuk była dopiero i tylko oczekiwanym wydarzeniem) z inicjatywy Instytutu Polskiego w Sofii, specjalny obszerny numer „Literaturen Vestnik” pod redakcja Margrety Grigorovej i Silvii Borisovej o Nagrodach Nobla przyznanych do tej pory Polakom. Na szczęście okazało się, że w trakcie pracy nad numerem (wydanie było zaplanowane na 11 grudnia) grono polskich noblistów poszerzyło się i najnowsza laureatka zasłużenie 
zajęła miejsce na pierwszej stronie czasopisma. 7 grudnia wysłuchaliśmy wykładu noblowskiego Tokarczuk, a jego fragmenty w tłumaczeniu Silvii Borisovej opublikowaliśmy w owym numerze „Literaturen Vestnik” (Токарчук 2019d, 6). W czasopiśmie znalazł się również rozdział z Ksiag Jakubowych (Токарчук 2019c, 9), fragmenty wcześniejszych bułgarskich przekładów utworów noblistki, urywki tekstów krytycznych oraz - za zgodą pisarki informacja o najnowszej, jeszcze niedokończonej książce.

10 grudnia w Instytucie Polskim została zorganizowana publiczna projekcja uroczystości noblowskiej, wykładu oraz mowy bankietowej Olgi Tokarczuk. Studenci poloniści Uniwersytetu Wielkotyrnowskiego przedstawili prezentacje o polskich noblistach.

W tygodniu noblowskim ukazała się książka Изzyбeната dyша [Zgubiona dusza] (Токарчук 2019e), wydana w Polsce w 2017 roku bajka dla dorosłych, przypominająca utwór Oscara Wilde’a Rybak i jego dusza. To arcydzieło, w którym tekst Tokarczuk jest w pełni zharmonizowany z rysunkami Joanny Concejo, stało się być może najpiękniejszym nowym symbolem obecności pisarki w Bułgarii, łączącym się ze słowami wygłoszonymi z noblowskiej trybuny. Przesłanie bajki współbrzmi ze wzruszającym i mądrym odczytem noblowskim Cquły narrator, którego połowę opublikowano w miesięczniku „Kultura” w przekładzie Mileny Milevej (Токарчук 2020). Obecnie przygotowywane jest dwujęzyczne wydanie wykładu.

18 grudnia 2019 roku na portalu Kultura swoje teksty o Nagrodzie Nobla przyznanej Oldze Tokarczuk opublikowali: jej wieloletni przyjaciel i pisarz Georgi Gospodinov, Silvia Choleva - poetka i wydawczyni trzech książek noblistki (Музика на много барабани [Gra na wielu bebenkach], Последни истории [Ostatnie historie] i Бегуни [Bieguni]) oraz pisarka Vesela Luckanova. Każde z nich opowiedziało o pierwszym i kolejnych spotkaniach z Olga Tokarczuk. W przypadku Gospodinova znajomość ta trwa od około dwudziestu lat, w przypadku Luckanovej - piętnaście lat, a w przypadku Cholevej od 2013 roku, kiedy poznała polską pisarkę w Słowenii, gdy Tokarczuk wręczano nagrodę Vilenica (Господинов, Чолова, Аюцканова 2019).

Nagrodę Nobla przyznano polskiej pisarce w najodpowiedniejszej chwili, „nie było lepszego momentu, żeby dostać Nobla” (Tokarczuk 2019f) - potwierdza noblistka, co natychmiast przywodzi na myśl formułę z Biegunów o właściwym czasie i miejscu, w którym być może dzieją się jakieś ważne wydarzenia (Tokarczuk 2008, 90). Przyznanie Nagrody Nobla nastapiło właśnie wtedy, kiedy trzeba było zwrócić się do czytelników. Dzięki słowom wypowiedzianym z trybuny twórczość noblistki stała się bardziej słyszalna. 
Tokarczuk jest mistrzynią zaszczepiania idei budzących świadomość cudu istnienia i cudu duszy, uzmysławiających miejsce człowieka we wszechświecie. Już na początku odczytu noblowskiego można odnieść wrażenie, że pisarka prowadzi narrację o istnieniu, którą jakby samo uniwersum opowiada dziecku. Anteny starego radia odbieraja głosy z różnych galaktyk, a jeszcze nienarodzone dziecko może je usłyszeć. Autorka mówi: „wsłuchajcie się w kosmos" i „wsłuchajcie się w siebie”, a kiedy się wsłuchujemy, wychwytujemy rytm serca: czy to naszej matki, czy pramatki Wszechświata. One nakładają się jeden na drugi i na tym polega cud istnienia. Tokarczuk, mistrzyni autorefleksji, powtarza tu kluczowe słowo z początku Biegunów - „Jestem" i wtedy uświadamiamy sobie, że jesteśmy tu, że tu i teraz czujemy, że jesteśmy i myślimy o naszym istnieniu. Odczyt daje nową możliwość usłyszenia głosu autorki, jej trwogę, ale i nadzieję, jej sposób obmyślania świata, gdy wstępuje w rolę narratora.

Tokarczuk liczy się z tym, że odbiorców ze wszystkich krajów łączy jednakowy sposób postrzegania zjawisk. Dlatego na pytanie: „Co daje pani to, że może się pani komunikować poprzez literaturę z czytelnikami z innych krajów, którzy pewnie też inaczej pani książki odbierają inaczej trochę interpretuja?" Tokarczuk odpowiada właśnie w tym duchu:

Nie, właśnie nie inaczej! To, czego się nauczyłam od momentu, kiedy moje książki zaczęły być tłumaczone, to to, że odbiór literatury jest wszędzie naprawdę bardzo podobny, jeśli nie taki sam. Oczywiście, zdarzają się może jakieś drobne nieporozumienia, niedorozumienia, ale tak naprawdę to, czego literatura dotyka, to głębokie, podstawowe poziomy naszej psychiki. A ta psychika wszędzie jest taka sama - bez względu na to, jakim językiem mówimy, w jakim klimacie żyjemy. To jest ta niesamowitość, ten cud literatury. Literatura pokazuje nam, że jesteśmy dużo bardziej do siebie podobni, niż nam się wydaje (Tokarczuk 2019f).

Bajka Zgubiona dusz̧a, której głos współbrzmiał w Bułgarii z przesłaniem odczytu noblowskiego, odkrywa nowy etap twórczy autorki, nowe przesłanie, które kieruje ona do ogółu ludzkości i każdego z osobna. Swoim bajkowym happy endem uspokaja oraz leczy zmęczone i zranione dusze naszego przyśpieszonego, zmechanizowanego świata. Zawarta w Biegunach idea ruchu i podróży (zgodnie z którą nasz świat to wspólna przestrzeń wędrowców, a my jesteśmy skazani na wieczną tułaczkę, by uniknąć zła) jakby spotyka się tu z kojącym przeciwdziałaniem. Przyśpieszenie jest zbyt duże, może wywołać w nas spustoszenie, możemy zapomnieć o swoich duszach tak, jak boha- 
ter książki zapomniał o swoim imieniu i nie wiedział, jak ma rozmawiać sam ze soba. Musimy zatrzymać świat w sobie, poszukać kontaktu ze swoją duszą i cierpliwie dbać o nią, przypomnieć sobie o swoim wewnętrznym mirze, by odetchnąć, zmęczeni zewnętrznym światem. Podobnie jak bohater powieści Labirynt swiata $i$ raj serca (znanego Tokarczuk Comeniusa, Jana Amosa Komeńskiego) wraca z podróży po labiryncie do domu duszy, żeby zadbać o nią i żeby odnaleźć nieistniejące wyjście. Warto zauważyć, że pisarka wspomina Comeniusa w swoim wykładzie w związku z jego encyklopedyczną ideą pansofii, która niestety najpierw się spełniała, a potem rozpadła w kulturze sieci.

Nasuwa się tu skojarzenie z Wisławą Szymborską i jej wierszami z tomu Wystarç̧y, w których poetka zwraca uwagę na duszę w autorefleksji o istnieniu, czyli w Wyznaniach maszyny czytajacej (Шимборска 2012). Maszyna ma największe kłopoty z wyrazami „dusza” („rodzaj mgły rzekomo od śmiertelnych organizmów trwalszy”) i ,jestem” (pozornie „czynność pospolita, uprawiana powszechnie, ale nie zbiorowo, w praczasie teraźniejszym, w trybie niedokonanym, choć, jak wiadomo, dawno dokonanym”). Definicje czasami nie wystarcza, wręcz przeciwnie - zakłócają mechanizmy odczytania i zrozumienia.

W odnalezieniu duszy pomagają Oldze Tokarczuk rysunki. Po raz kolejny (po Biegunach i Ksiegach Jakubowych) są one ważnym elementem wizualnym w tekstach noblistki - od różnych rodzajów map w Biegunach i Ksiegach Jakubowych po obrazy Joanny Concejo, które są nowym magicznym narzędziem sugestii. Rysunki tworzą świat, w który można wejść, tak jakby animowały one bajkę, przemieniają ją w film, dopełniają treść wyrażoną słowami poprzez swe wizualności. Ilustracje dają obraz duszy i okazuje się, że... jest ona dzieckiem. Musimy częściej rozmawiać z sobą porozumiewając się z dzieckiem, które jest w nas, musimy o nie dbać. Myślę, a nawet jestem przekonana, że dzisiejszy świat po raz kolejny odkrywa dziecko. Powrót duszy oddziałuje na światy roślinny i zwierzęcy, które żyja z nami w harmonii. Można tu znów nawiązać do Szymborskiej - rośliny u obu noblistek czują i coraz mocniej rozwijaja swoje liście oraz kwiaty. Warto przypomnieć przepiękne wydanie tomu wierszy Milczenie roślin Szymborskiej - w podobnym stylu jak Zgubiona dusza - z ilustracjami, w pięknej szacie graficznej, która prezentuje królestwo roślin. Tak powinny wygląać książki, piękne duszą i ciałem, żeby można było odbierać je czysto fizycznie, zachwycać się nimi jak skarbami.

Laur Olgi Tokarczuk warto też wpisać w bułgarski kontekst: chodzi o doskwierający nam brak Nagrody Nobla w dziedzinie literatury, choć być może 
brzmi to trochę paradoksalnie. Wiele razy byliśmy blisko, lecz do tej pory nie możemy poszczycić się tym wyróżnieniem ${ }^{3}$. W recepcji literatury polskiej w Bułgarii - co łączy się zawsze z tym procesem - działają mechanizmy kompensacyjne (pozytywny stosunek do tego, czego w rodzimej literaturze nie ma lub jest inne). Dlatego Nagrody Nobla przyznane polskim pisarzom w jakimś sensie wzbogacają nas samych, kiedy jesteśmy odbiorcami literatury polskiej i się nią zajmujemy. Zdajemy sobie także sprawę z rozmaitych okoliczności, efektów i paradoksów przyznawania nagród. Wspomniana kwestia okazała się szczególna drażliwa po wydaniu monografii Amelii Lichevej pt. Czy Nobel jest światowy? (Аичева 2019) - promocja książki zainicjowała ożywione dyskusje na ten temat.

Chociaż Olga Tokarczuk mówiła podczas ceremonii o Nagrodach Nobla przyznanych polskim pisarzom jako o wyróżnieniach dla niewielkiego narodu i literatury pisanej w mało znanym języku, osiagnięcia polskich literatów są wielkie, a Literackie Nagrody Nobla są tego faktu uznaniem i świadectwem.

\section{Olga i Georgi}

Na szczególne wyróżnienie zasługuje pokrewność twórcza i wieloletnia przyjaźń Olgi Tokarczuk z Georgim Gospodinovem, który 10 lat temu wywróżył jej Nagrodę Nobla. Warto zauważyć, że podczas Międzynarodowego Festiwalu Literatury im. Josepha Conrada w Krakowie Olga Tokarczuk wskazała Gospodinova jako najbliższego sobie innojęzycznego pisarza.

Czytając Georgiego, widziałam jego podobne rozpoznania, rozwiązania i zawsze, jak czytałam Fizyyke smutku, którą uważam za wybitną książkę, piękna, dojmująca, świetnie napisaną jak rozpoznawałam tam jakieś takie rzeczy, których i ja używałam, to miałam takie poczucie entuzjastycznej radości, że to ktoś jeszcze tak samo zobaczył i próbował opisać w inny sposób, w innym kontekście, ale że to jest jakaś taka wspólnota doświadczenia, coś nas nagle zaciekawiło i co się potem znajduje na kartach książki (Tokarczuk 2019g).

\footnotetext{
${ }^{3}$ W 2011 roku na Uniwersytecie w Velikim Tyrnovie odbyła się międzynarodowa konferencja, poświęcona Literackiej Nagrodzie Nobla i setnej rocznicy urodzin Czesława Miłosza. Pokłosiem tego spotkania jest tom pokonferencyjny pt. Нобеловата награда за литература - мост межdy кyлmypume [Literacka Nagroda Nobla - most pomiedsy kulturami] (Григорова изА. 2013).
} 
Podobnie wypowiada się o Tokarczuk Gospodinov: „Jestem przekonany, że dobrymi książkami są te, które stanowią klucz do osobistych historii, do twoich historii. Z książkami Olgi to mi się ciągle przytrafia” (Господинов, Чолева, Аюцканова 2019).

Jak opowiada bułgarski pisarz, poznali się 20 lat temu w Berlinie. Kiedy wydano w Polsce jego Powiesć naturalna, Olga Tokarczuk napisała opinię wydawniczą o książce. Tego samego dnia, kiedy we Wrocławiu Gospodinov otrzymał Literacką Nagrodę Europy Środkowej „Angelus”, miasto witało Olge Tokarczuk po odebraniu Nagrody Nobla. Oboje przepowiedzieli sobie otrzymanie tych wyróżnień. Często się spotykali i rozmawiali, dyskutowali na przykład o snach i śnieniu, o pograniczu między jawą i snem.

Bliskość pisarstwa Tokarczuk i Gospodinova widoczna jest też na płaszczyźnie genologicznej - nie tylko w zamiłowaniu do opowiadania czy fragmentarycznej struktury powieści, ale też do tematyki baśniowej. Gospodinov stał się bardzo popularny jako autor bajki Cıяnama Baŭm [Ślepa Vaysha], na podstawie której powstał film animowany w reżyserii i według scenariusza Teodora Usheva pt. Blind Vaysha (2016), nominowany do Oscara 4 . Sięgnięcie po baśń oraz istotna w niej rola wizualizacji to elementy łączce warsztat pisarski obojga pisarzy. Wspólne jest też przesłanie ich twórczości.

\section{Wizyta Olgi Tokarczuk w Bułgarii w 2014 roku}

Olge Tokarczuk zapraszano do Bułgarii kilkakrotnie, zwykle w związku z ukazaniem się kolejnych przekładów jej książek. Jednak pierwsza wizyta pisarki w naszym kraju miała miejsce dopiero w 2014 r., w ramach Polskiej Jesieni Literackiej, zorganizowanej przez Instytut Polski w Sofii, i była bezpośrednio związana z promocja świeżo wydanej książki Kapaŭ nлyza cu nрез костите на мъртвите [Prowadź swój plug przez kości umarlych]. Spotkania z czytelnikami odbyły się 4 listopada (w Sofii) i 5 listopada (w Płowdiwie). Rozmowy toczyły się przede wszystkim wokół nowo opublikowanej książki, jej przesłania, filozofii, Williama Blake’a, którego twórczość może być kluczem

\footnotetext{
${ }_{4}$ Zob. Blind Vaysha, reż. T. Ushev, https://www.youtube.com/watch?v=Tsa6jM5Hvy8 [dostęp: 10.01.2020].
} 
do odczytania utworu. Olga Tokarczuk miała też ze sobą Ksiegi Jakubowe, więc niektóre pytania dotyczyły również tej powieści ${ }^{5}$.

Tokarczuk spotkała się przy tej okazji z Georgim Gospodinovem, z tłumaczką wielu swoich powieści - Silvią Borisova, z poetką i dziennikarką Silvią Cholevą ${ }^{6}$. Oprócz tego polska pisarka udzieliła niemało wywiadów.

Olga Tokarczuk jest mistrzynią eksplikacji. Warto by wydać przeprowadzone z nia rozmowy w formie audiobooka (byłby obszerny, bo jest ich dużo), żeby można było słuchać jej głosu (powiedziałabym, że ma on działanie terapeutyczne), rejestrować formułowane idee. Wywiad przed premiera książki Kaрай nлyza си през костите на мъртвите [Prowadź swój plug præę kości umarlych] prowadził dziennikarz z Radia FM Svetoslav Nikolov (Токарчук 2014c). Rozpoczął od cytatu, wyrażającego kluczową dla tego dzieła myśl o nieznośnie bolesnym odbiorze nierozerwalnego świata, w którym wszystko jest powiązane, niezależnie od tego, gdzie się dzieje. Przywołany przez Nikolova fragment służy pisarce do ujawnienia swojego poglądu na temat empatii, do której nie jest zdolnych ok. 20\% ludzi na świecie, mówi o zagrożeniu przez gotowe formuły myślenia i życia, z powodu których ludzie nie dociekają czegoś sami, lecz ich postrzeganie jest inercjalne i mechaniczne, mówi też o sposobie, w jaki moglibyśmy się temu przeciwstawić. Warto wsłuchać się w jej rozmyślania:

Kiedy patrzymy tak globalnie, to boli nas każda wojna za granica, to boli nas każde głodne dziecko w Afryce, dlatego to nie dziwne, że nie chcemy żyć w taki sposób, nie chcemy czuć tego wszystkiego. Duszejko, ta szalona kobieta z mojej książki, mówi, że gdybyśmy mogli wszystko ujrzeć naraz, to by serce nam pękło. (...) W jaki sposób ten uczciwy stosunek do siebie i do świata mógłby zmienić świat? Zdaje mi się, że całym nieszczęściem żyjącego dziś człowieka, zanurzonego w popkulturze, mediach $\mathrm{i}$ internecie, jest to, że on jakby przestaje myśleć samodzielnie, że dostaje jakby takie gotowe formy myślenia i one są jakby odłączone jedna od drugiej i gdyby można je było połączyć, to zobaczyłoby się rzeczy w ich całym głębokim wymiarze, w jakim one sa. Wtedy można postawić właściwą diagnozę i próbować coś zmienić (Токарчук 2014c).

5 W kolejnym roku opublikowano esej pt. Jak napisałam „Ksiegi Jakubowe”, w tłumaczeniu Kruma Krumova (Токарчук 2015, 12).

${ }^{6}$ Choleva przeprowadziła wywiad z Olga Tokarczuk w 2013 roku - po spotkaniu na środkowoeuropejskim festiwalu literackim w Słowenii, podczas którego przyznawana jest literacka nagroda Vilenica (Токарчук 2013). 
Kolejną rozmowę prowadził z Olgą Tokarczuk dla „Literaturen Vestnik” Chavdar Parushev. Trudno wymienić wszystkie poruszone w wywiadzie wątki, najważniejsze to: istota przekraczania granicy między transcendentnym i codziennym, znaczenie Blake'a patronującego książce i jego koncepcji obrony zwierząt, geopoetyka Kotliny Kłodzkiej i fakt, że właśnie tam mieszkali czterej polscy tłumacze Blake'a, pełne zaufanie do tłumaczki Silvii Borisovej, która Tokarczuk nazywa „akuszerką” bułgarskiego wydania swojej książki. Odpowiadając na pytanie, kto z bułgarskich ludzi pióra przykuł jej uwagę, Pisarka najpierw zauważa, że niewiele bułgarskich utworów przełożono na język polski. Jesienią 2014 roku powieściopisarka wyznała:

Tylko książki Georgiego Gospodinova zostały przetłumaczone. Fiæ̌y/ke smutku znam tylko z fragmentów. Lecz on naprawdę w pewnym sensie wyczerpuje moje wyobrażenie o literaturze bułgarskiej, ponieważ jest pisarzem wysokiej klasy. I Silvia Choleva, oczywiście, z którą poznałyśmy się na festiwalu w Vilenicy, ona też jest świetną poetką (Токарчук 2014b, 7).

Inne przestrzenie twórcze otwiera wywiad Petrany Petrovej, opublikowany na stronie internetowej Az cheta [Ja czytam] (Токарчук 2014a), przeprowadzony po sofijskiej premierze książki i przed wyjazdem Tokarczuk do Płowdiwu. Znalazły się w nim wyznania pisarki o najciekawszych jej kontaktach z czytelnikami, o tym, że wszyscy bohaterowie książek są jej cząstkami, o słowach kluczowych takich, jak np.: gniew, teoria, sarna, pisanych wielką litera, aby podkreślić ich głębsze znaczenie, o pisaniu powieści Prawiek. $i$ inne czasy, w której Tokarczuk spoiła i uzupełniła opowiadania swojej babci.

W niektórych wywiadach (a było ich siedem) podkreślano znaczenie drugiego imienia noblistki (tłumaczka zamieściła je w przekładzie książki Prowadź swój plug przez kości umarlych) - Nawoja 'osoba buntownicza'. Ta część osobowości Tokarczuk zaintrygowała bułgarskich czytelników; poznali jej zdanie na temat sprzeciwu oraz doświadczyli absorbującej siły jej myśli, które zawsze wskazuja jakby inne, ukryte wymiary świata, Wszechświata i istnienia, o których często się zapomina. Stykając się z jej książkami, bułgarscy czytelnicy byli z Olga Tokarczuk w Prawieku, potem wędrowali z jej biegunami, a mapa tej tułaczki miały być nie tylko przestrzenie geograficzne, ale także czasowe, wreszcie też nasze dusze i ciała. Tokarczuk uczyła nas w Domu dziennym, domu nocnym, że tam, gdzie ludzie wytyczaja granice, istnieje świat „pomiędzy”. Jej smutne Ostatnie historie przekazuja prawdę o śmierci, która może zmienić świadomość życia. Coraz lepiej rozumiemy świat zwie- 
rząt dzięki ich bliskości w Prowadź swój plug przę kości umarlych. Żeby ostatecznie wrócić do domu i do siebie w świecie baśni, przynoszącej ukojenie duszy.

\section{Literatura}

Атанасова К., 2019, „Бегуни“ на Олга Токариук - живот някъде другаде, http://www.kultura. bg/article/272-zhivot-nyakyde-drugade [dostęp: 10.01.2020].

Борисова С., 2019а, Абсолютна съвременност на идеите, говор. Бурова А., „Аитературен вестник", брой 35.

Борисова С., 2019b, В ключа на разказа, говор. Атанасова K., http://www.kultura.bg/arti cle/272-zhivot-nyakyde-drugade [dostęp: 10.01.2020].

Господинов Г., Чолева С., Аюцканова В., 2019, Нобел за Олга Токариук, http://kweekly. bg/publication/4993 [dostęp: 10.01.2020].

Григорова М., изА., 2013, Нобеловата награда за литература - мост между културите. Международна научна конферениия. 1-3 декември, Велико Тьрново.

Аичева А., 2019, Световен ми е „Нобел“?, София.

Tokarczuk O., 2008, Bieguni, Kraków.

Токарчук О., 2013, За мен е добре да съм от периферията [Dla mnie lepiej naležé́ do peryferii], говор. Чолева С., „Аитературен вестник”, брой 33.

Токарчук О., 2014а, Олга Токариук: Моето писане е вид обиуване с другия човек, говор. Петрова Р., прев. Борисова C., https://azcheta.com/olga-tokarchuk/ [dostęp: 10.01.2020].

Токарчук О., 2014b, Смятам, че един ден писателят трябва да изпробва силите си в тьй наречения жанров роман, говор. Парушев, Ч., прев. Борисова С., „Аитературен вестник”, брой 36.

Токарчук, О., 2014c, Болката да познаваш света, свободата да живееш истински: полската писателка Олга Токарчук в студиото на Ажаз $Ф М$, говор. Николов, С., прев. Борисова С., http://www.jazzfm.bg/bg/interviews/bolkata-da-poznavash-sveta-svobodata-da-jiveesh-is tinski-polskata-pisatelka-olga-tokarchuk-v-studioto-na-djaz-fm [dostęp: 10.01.2020].

Токарчук О., 2015, Как написах „Книгите на Якољ” [Jak napisatam „Ksiegi Jakubowe”], прев. Крумов К., „Аитературен вестник”, брой 30.

Токарчук О., 2019а, Гранищата [Rubiè்], прев. Борисова С., „Аитературен вестник”, брой 35.

Токарчук О., 2019b, Как иреводачите всеки ден спасяват света [Powiem wam, kto uratuje świat], прев. Борисова С., „Аитературен вестник”, брой 30.

Токарчук О., 2019с, Книгите на Якуб (фрагмента) [Ksiegi Jakubowe] (fragment), прев. Борисова С., „Аитературен вестник”, брой 41.

Токарчук О., 2019d, Чувствителният повествовател (фрагменти) [Cұ̈ly narrator] (fragmenty), прев. Борисова С., „Аитературен вестник”, брой 41.

Токарчук О., 2019е, Изгубената душа [Zgubiona dusza], прев. Борисова С., София.

Tokarczuk O., 2019f, Olga Tokarczuk dla Onetu: nie byto lepszego momentu, żeby dostać Nobla, rozm. przepr. Padoł E., https://kultura.onet.pl/wywiady-i-artykuly/olga-tokarczuk-wyw iad-z-laureatka-literackiego-nobla/b915q7r [dostęp: 10.01.2020]. 
Tokarczuk O., 2019g, Zapytaj Olge! (Spotkanie z noblistką podczas Conrad Festival 2019), rozm. przepr. Markowski M.P., https://www.youtube.com/watch?v=plAETYPZL_0 [dostęp: 10.01.2020].

Токарчук О., 2020, Нежния разказвач [CZuly narrator], прев. Милева М., „Култура”, nr 1. Шимборска В., 2012, Аостатьчно [Wystarczy] (последни стихове), прев. Аеянова В., „Аитературен вестник”, брой 22.

Margreta Grigorova - prof. dr hab., Katedra Slawistyki, Wydział Filologiczny, Uniwersytet św. św. Cyryla i Metodego w Wielkim Tyrnowie, Bułgaria.

Interesuje się przede wszystkim literaturą polską w kontekście literatur słowiańskich i środkowoeuropejskich. Ostatnio badała temat herezji we współczesnej literaturze polskiej, relacje literatura-sztuka, bułgarską recepcję literatury polskiej, literackie motywy ruchu i podróży, między innymi w twórczości Josepha Conrada, Gustawa Herlinga-Grudzińskiego, Ryszarda Kapuścińskiego czy Olgi Tokarczuk. Jest autorką książek: Хоризонти и пътища на полската идентичност [Horyzonty i drogi polskiej tożsamości] (2002), Литературни посвещения. Ритуални зони на словото в полската литература [Rytualne strefy słowa w literaturze polskiej] (2004), Джоузеф Конрад Коженьовски. Творецьт като мореплавател [Joseph Conrad Korzeniowski. Pisarz jako żeglarz] (2011), Oczyma słowa. Studia polonistyczne (2015). Opublikowała ponad sto artykułów, w tym ponad trzydzieści na łamach polskich czasopism. Tłumaczka literatury polskiej: Rodzinna Europa Czesława Miłosza (2012) (wraz z Marią Kostovą), Książka twarzy Marka Bieńczyka (2015), Pianista. Wspomnienia Warszawskie Władysława Szpilmana (2019). Przełożyła wiersze Wisławy Szymborskiej, Romana Honeta, Zbigniewa Herberta, Jerzego Lieberta, reportaże Kazimierza Nowaka, opowiadania Gustawa Herlinga-Grudzińskiego oraz teksty krytycznoliterackie. Jest członkiem Polskiego Towarzystwa Conradystów oraz Międzynarodowego Stowarzyszenia Polonistów. Otrzymała odznakę honorową "Zasłużony dla Kultury Polskiej” (2014), nagrodę „Polonicum” Uniwersytetu Warszawskiego (2018) oraz Złoty Krzyż Zasługi (2019).

Kontakt: m.grigorova@ts.uni-vt.bg 